AGRARIS: Journal of Agribusiness and Rural Development Research

Vol. 7 No. 1 January-June 2021, Pages: 11-23

Article History:

Submitted: October $3^{\text {rd }}, 2020$

Accepted: November $21^{\text {st }}, 2020$
Ndivhoniswani Nephawe, Marizvikuru Mwale*, Jethro Zuwarimwe, and Malose M. Tjale

University of Venda, Institute for Rural Development, South Africa

*)Correspondence email: marizvikuru.manjoro@univen.ac.za

\title{
The Impact of Water-Related Challenges on Rural Communities Food Security Initiatives
}

\author{
DOI: https://doi.org/10.18196/agraris.v7i1.9935
}

\begin{abstract}
Water scarcity has been a critical concern in many countries of the world. The same concern has been discussed, analyses and researched at different platforms to find better solutions to the challenges of water scarcity, and in most cases water scarcity directly influence food security in terms of food production. South Africa, being one of the water scarce countries that derives its food from the agricultural sector; water scarcity remains at the center stage of the national socioeconomic debate. Water scarcity is one of the major challenges in many countries such as Zimbabwe and Ethiopia particularly for the farmers. However, there is insufficient information on the impact of water scarcity challenges on rural communities' food security initiatives. This review is focused on unearthing water scarcity challenges in rural communities, their impact on agriculture and ultimately food security initiatives. This paves way for possible research areas, practical implications and strategies to mitigate water security effects on food security.
\end{abstract}

Keywords: Food security, Resilience, Smallholder famers, Water scarcity, Water security

\section{INTRODUCTION}

Water has been a central issue on the international Agenda for several decades, and it is regarded as the most important resource for life (Mancosu et al., 2015). In some of the European countries, water scarcity is already a recurring problem. Water continues to be a problem even in the African continent where most of the Sub-Saharan regions are severely affected by lack of water due to drought, low rainfall and minimal water storage resolution. As compared to other countries, South Africa is vulnerable to droughts and high temperatures throughout all seasons as a result Smallholder Irrigation Scheme (SIS), which was introduced as response to this unforeseen condition. The focus in establishing SIS had been in rural areas where most of the people still practice farming in one form or another. Most of this SIS became a rapid remedy to hunger and poverty in rural villages and outskirts. They become an answer to food production employment and rural development at large. Food and agriculture organization indicated that smallholder agriculture is the mainstay of food production in the world's developing countries and is the key to ensuring long-term global food security. 


\section{RESEARCH METHOD}

The study employed an exploratory case study design to understand context specific challenges at the irrigation scheme. The rational to use the methodology for this paper is that extreme or unique cases may occur that justify a study in its own right. In this regard an intensive study of one instance or a small number of instances is undertaken in order to produce detailed descriptions of these cases (Thomas, 2004). This kind of research design is economical and generalizes results for the whole population. However, high costs of conducting the project and limited time were major limitations in conducting research at the irrigation scheme.

\section{RESULT AND DISCUSSIONS}

\section{Causes of Water Scarcity Globally and in Africa}

In many regions in Europe, climate change impacts on water resources and threatens the sustainability of the agricultural system. The increased occurrence of drought and water scarcity is predicted in many regions throughout Europe, and recent events over the last ten years have demonstrated that drought episodes typically for Southern European countries are expanding to Eastern and Western Europe (Hunink et al., 2019). Some Asian countries such as the Arabic states are also affected by lack of water e.g Saudi Arabia, whereas most of the African states are affected by drought and climate change causing water scarcity to be very devastating. Africa is the most vulnerable region notably exposed to the impact of climate variability and climate change. In Africa, agriculture forms the backbone of most of the continent's economies, providing about $60 \%$ of all employment. During the last decade per capita, agricultural production has not kept pace with population growth. Irrigation is a very old practice, dating back to the earliest civilization of humankind. It served as one of the key drivers behind the growth of agricultural productivity, increasing household income and alleviation of rural poverty, thereby highlighting the various ways that irrigation can impact on poverty (Mengistie \& Kidane, 2016). In order to meet food requirements by 2020, Food and Agricultural Organization (Food and Agriculture Organization, 2000) has estimated that food production from irrigated areas will need to increase from 35\% in 1995 to $45 \%$ in 2020 . This indicates that access to water for irrigation will become a global concern, especially in the arid and semi-arid regions of the world (Mengistie \& Kidane, 2016). An example of water scarcity countries in Africa is Ethiopia (Azene et al., 2018). This was also supported by Taye, Dyer, Hirpa, \& Charles (2018) who indicated that Ethiopia is an example of a country whose river basins are vulnerable to changes in climate.

The adoption of sustainable water management and irrigation development programs is essential for water security. Furthermore, strong linkages with private sectors and markets with institutional support are also essential elements that ensure water security. These could provide plenty of opportunities in terms of coping strategy for climatic change, poverty reduction, wealth creation, growth of economy and reducing the environmental impact of 
agricultural expansion to marginal land under rapid population growth (Mengistie \& Kidane, 2016). Directly or indirectly, Smallholder Irrigation Scheme (SIS) has positive impact on food security, asset ownership and well-being of rural farm households. There are also clear increases in agricultural production through diversification and intensification of crops grown, household income, sources of animal feed, human health improvements, and assets ownership (Mengistie \& Kidane, 2016).

In 2003, the African ministerial council on water programs and actions were articulated under the New Partnership for African Development (NEPAD) framework. One of the 21 targets in the millennium development goals is to reduce the proportion of people without sustainable access to safe drinking water and basic sanitation by $50 \%$ by 2015 . Hence Sustainable Development goal six (SDG 6) targeted to increase water-use efficiency across all sectors and ensure sustainable withdrawals and supply of freshwater to address water scarcity and substantially reduce the number of people suffering from water scarcity by 2030. Water scarcity has not impacted on water for the basic needs, but it also affected agricultural production, resulting in increased food scarcity concerns (Esmaeili \& Vazirzadeh, 2009). World-wide, irrigation water still remains an essential input in agricultural production (Esmaeili \& Vazirzadeh, 2009). The sustainable development goals (SDGs) report indicates that although progress has been made towards better food security, hunger remains an issue in many households in South Africa (Dotse, 2016). Most of the smallholder famers' schemes remain dysfunctional due to water related challenges such as lack of water storage, poor or out dated water supply systems and lack of resources to water the crops.

It is very important to note that most of the smallholder's irrigation schemes were implemented to help produce more fresh produces, to be a solution during drought periods and create employment to alleviate poverty. Most of these smallholders' schemes were situated near rivers, fountains or dams where there is running water. South Africa is a water scarcity country which relies mainly on agricultural activities for its food production (Fanadzo \& Ncube, 2018). In most cases water used in irrigation schemes in most of South African provinces was not conserved, but of late, the Municipalities and local governments have started building dams, reservoirs and erecting bulk water tanks. It is only during the new government period from 1994 where the state is trying to make measures to conserve water for household and irrigation purposes. It is crucial for water to be conserved in order to use it productively and economically, though water supply to irrigation schemes may be considered costly. It is important for irrigation scheme members to gain more professional training on how to get water into their schemes. It is possible to reduce water consumption on a large scale, without significant sacrifices in the day to day life of South Africans e.g. the municipality water tariffs and famers associations including famers' cooperatives (Crookes et al., 2018).

In Limpopo and Mpumalanga, the backlogs on the establishment and renewal of the smallholder schemes are attributed to water scarcity since human settlements are located in 
scarce river catchments, and developments are primarily hampered by lack of water resources and related bulk infrastructure (Crookes et al., 2018). Major bulk water resource development as well as bulk infrastructure planning and development are underway such as De Hoop dam and Nwamitwa, and this development will take several years (Crookes et al., 2018). Small irrigation schemes must, therefore, secure water rights in order to be part of water transformation program introduced by water user's association (Tlou et al., 2006).

In Limpopo the most contributing factor to water scarcity is the untimely drought. During the drought period most rivers dry up affecting the irrigation schemes which are dependent on these rivers for irrigation water. Secondly the climate change in more devastating to the irrigation schemes as the extreme high temperatures hamper the anticipated production. Low rainfall in the province makes productivity unpredictable. Most of the irrigation schemes in Limpopo are not yet modernized, living them running on high costs as they still embark on primitive ways of irrigation (Maponya \& Mpandeli, 2016) . An example of Luvhada irrigation scheme in Nzhelele, Vhembe District does not differ with the rest of irrigation schemes in Limpopo Province mentioned by Maponya and Mpandeli above. The Luvhada irrigation scheme was established by King P.R Mphephu (former Venda land president) in the 1960s. The Luvhada irrigation scheme is regarded as one of the major solutions to food security and poverty alleviation programs. Mpumalanga province as compared to Limpopo Province, remains the largest production region for forestry, and the majority of the people living in Mpumalanga are farmers who contributed immensely to promote food security. However, due to the threat by climate variability and change, sectors such as the Agriculture, and water affairs etc. are experiencing pattern such as putting livelihoods and food production at serious risks due to extreme climate events, climate variability and climate change (Maponya, Mpandeli, \& Oduniyi, 2013).

\section{The Impact of Water Security in Agriculture}

Drought is a serious challenge in Limpopo province (Maponya \& Mpandeli, 2016). Considering the fact that the province is in semi-arid area with low, unreliable rainfall, these has negative effects on the agricultural sector, resulting in decreased agricultural activities, loss of livestock, shortage of drinking water, low yields and shortage of seeds for subsequent cultivation. These was also affirmed in 2015 by the by the Limpopo department of Agriculture (2015) that Limpopo was declared a drought disaster area. Other provinces that were declared drought disaster areas with water crisis were North West, KwaZulu-Natal, Mpumalanga, and the Free State. However, Limpopo province is drought prone province which face challenges of drought from time to time. As a result of the severe drought, the province experienced low water supply for irrigation which negatively impacted the agricultural sector (Maponya \& Mpandeli, 2012).

\section{Importance and Use of Water in Agriculture}

The majority of the non-operational smallholder schemes were those that involved pumping of water (Njoko, 2014). According to Averbeke, Denison, \& Mnkeni (2011), about $84 \%$ of the 90 non-operational schemes were gravity fed. This is because it is cheaper to 
derive water from running streams and cisterns and most of the smallholder's farmers prefer easy and cheaper way. This implies that there is a higher chance of gravity-fed smallholder schemes remaining operational compared to those involving pumping water. The overhead costs associated with pumps, and high maintenance of pump make Smallholder Irrigation Scheme unsustainable. According to (Darko et al., 2016), water scarcity in agriculture is becoming a major problem due to increasing demand for agricultural use, and intensive crop management on existing croplands to meet the needs of expanding global population. Thus, water scarcity ravels challenges on water supply and conservation for agricultural purposes.

\section{Negative Impact of Water Scarcity in Agriculture}

Water Supply and Conservation

In 2015, the Department of Agriculture, Forestry \& Fisheries (DAFF) stated that South Africa can no longer afford water losses, and, therefore, it is imperative that focus on water conservation and water demand measures must be strengthened. There is a great return on investment through water loss control and water use efficiency. The department will also prioritize the establishment of the water demand funding facilitation unit to provide support to municipalities in their effort to introduce water conservation and demand management (Crookes et al., 2018). The maintenance of water conservation and water supply are costly, leaving most of the water infrastructure not maintained for a long period of time (Schreiner et al., 2010). Hadebe, Modi, \& Mabhaudhi (2016) indicated that declining water availability or increasing water scarcity can have a negative impact on cropland and pasture productivity. These findings are supported by Meng et al. (2016) confirming that a failure to meet the water requirements of crops lead to decreasing yields of staple such as maize in the country.

\section{Water Supply}

Most of the farmers in the country are experiencing water supply challenges. There are only few commercial farmers using modern technology and techniques to maximize production, but it is difficult for small farmers and non-commercial farmers to afford modern machinery and equipment, since they are very costly. Farmers would like to see the state subsidizing non-commercial farmers and SIS to afford them improvements in productivity. One of the great challenges is to safeguard the supply for food production (Food and Agriculture Organization, 2011). This is generally approached through the adoption of farm management practices and technologies that are meant to increase water productivity (Haacker et al., 2019). Agriculture is the largest consumer of water, where the irrigation of cropland accounts for $70 \%$ of water withdrawals (McDaniel et al., 2017).Since the balance between water demand and water availability has reached critical concern in many regions of the world, increased for water and food production is likely to be sustained in future because of water resources management agriculture which is essential (Mancosu et al., 2015). 


\section{Water Conservation}

The building of dams and reservoirs need a lot of capital, hence it is important to conserve water in order to use it efficiently and productively. The private sector should assist with solutions on how to conserve water such as bulk water tanks reservoirs and dams, in order to improve food security. The above statement is supported by (Daus et al., 2019) that dams, reservoirs and bulk water tanks are the resources that can store and retain water which can be used fruitfully. According to Hamilton (2019), the private sector is increasingly recognizing that it is not immune to the global water crises which is ranked as one of the top five risks facing the world's economy since 2012. Thus, private sectors are assisting in acquiring bulk water tanks and reservoirs. Largely, the multinational companies to date are still responsible for the management of water. Hence, Koda, Girmay, Berihu, \& Nagumo (2019) indicated that using reservoir water for irrigation, can be a potential solution to simultaneously address soil and water constraints that increases food security challenges.

Water Storage

According to Crookes et al. (2018), the country has a good and satisfactory dam storage yielding an average of $81 \%$. Although dams in Limpopo, North West and Eastern Cape are at a lower capacity of around $70 \%$, however, the government is doing very well in conserving useful water. The only challenge is how water is being used from this storage (Crookes et al., 2018). In some rivers e.g., Vaal River, there is overuse of water which endangers the species and life span of the rivers concerned (Crookes et al., 2018). In the context of rural development, rural communities use water for a wide range of productive and domestic uses, which are important to their live hood. However, the water from streams, rivers and reservoirs is no longer enough to the increasing water demand in many rural areas under semi-arid conditions. Therefore, there is a need to promote water related technology. Many times people maintain that improving irrigation efficiencies would lead to water saving, which means that water would become available for other users or uses. Water storage through reservoirs and natural infrastructure provides intra-seasonal averaging of water availability and contributes to increasing climate resilience by contributing to the control of flooding (World Health Organization, 2009).

Water Scarcity and Food Security

Water is a critical driver of agricultural production (Gashu et al., 2019). Added to this, weak support services are a persistent problem in most SIS assessments (Machethe et al., 2004). However, training in farm and scheme management is needed to assist people in particular farmers to have knowledge on how to manage water in their farms. The provision of support to develop reliable networks for the marketing of products beyond the local environs is also critical (Averbeke et al., 2011). According to (Machethe et al., 2004), provision of these support services to smallholder schemes became the principal mandate of public agricultural extension some 18 years ago, following withdrawal of provincial departments of agriculture from active involvement in scheme management. Most of the 
small-scale irrigation schemes (SIS) have been dysfunctional for many years due to lack of managerial skills and infrastructural deficiencies. A number of such schemes are found in Limpopo and Eastern Cape provinces (Averbeke et al., 2011). The central government developed a reform program to revitalized small-scale irrigation schemes, whereby the municipalities and provincial governments are given funds by the National governments to assist smallholder farmers to re-establish and refurbish their schemes in order to be more productive (Yokwe, 2005). As a result, small scale irrigation schemes in South Africa are placed under the irrigation management transfer program (IMT). Numerous SIS in South Africa were planned and established following a centralized estate design (Fanadzo et al., 2010). According to Perret (2002), control and decision-making over farming activities was strictly enforced by central management, with little or no input from farmers, thus creating a high level of dependency among farmers in the schemes that contributed to poor performance when farmers were left to manage the schemes on their own.

Improving Water Usage and Food Security in Rural Communities

Food production is hugely impacted by water scarcity. Without water people do not have a means of watering their crops and therefore, to provide food for the fast-growing population. Water for food is one of the main global issues while irrigation is a limiting factor in agricultural production (Dotse, 2016). Agriculture remains the most likely route to escape poverty (Njoko, 2014). Since most of the rural people are employed in the agricultural sector where they get food and salaries to maintain their household. This is supported by findings from several studies that reported a strong positive relationship between increased agricultural productivity and poverty reduction (Njoko, 2014; Koppen et al., 2017). Small irrigation schemes in South Africa are essential for rural development, job creation, income generation and enhanced food security (Njoko, 2014). Hence Improvement in agricultural productivity could reduce rural poverty by ensuring a sustainable supply of food, reducing food prices, generating export earnings and higher income for farmers, increasing on-farm employment and farm wage rates, and by creating linkages between farming and other sectors that are drivers of the rural economy. Improving agricultural productivity will provide capital and labour for growth in other sectors of the economy (Gashu et al., 2019). Smallholder schemes produce a large part of their subsistence food requirements mainly to protect themselves from food insecurity arising from failure of marketing system.

\section{Resilience to Water Scarcity}

People- can play a major role in making sure that water is used properly and gainfully, so that there can be less risk of losing water unnecessarily. One way to do so is by birth control. Because population growth is influenced by high rate of birth, if people can reduce birth rate to a maximum of three per household, this would help to preserve, conserve and use water for a long period of time. Secondly if people can avoid unnecessary damage to environment i.e. cutting of trees, dumping dangerous chemicals in rivers, dams and avoiding water pollution, then the threat to water availability can be reduced. Hence, Simonovic \& 
Arunkumar (2016) indicated that water scarcity is due to global change in population growth, land use change and climate change. This is a serious concern since it can cause loss of human lives and seriously damage the economy of the country. Due to population growth and changes in lifestyle the demands towards the watercourses are constantly rising (Daus et al., 2019). Farmers can help to reduce water risk by taking care of the soil. Farmers can also use organic matter in soil through regenerative farming practices to make the land better able to retain the moisture and to withstand drought. The soil has more integrity and it's less likely to be washed away in a storm. Finally, farmers can advance regenerative agriculture practices to involve organic and conversional farmers and suppliers among others.

\section{CONCLUSION AND RECOMMENDATIONS}

\section{Conclusion}

Water scarcity is a challenge experienced by many countries in the world including South Africa. Some of the major causes of water scarcity in Africa are climate change, drought and population growth. The impact of water security in Africa are loss of livestock, low yields, shortage of seeds for subsequent cultivation, low water supply for irrigation, shortage of drinking water, and lower food production. Water scarcity in agriculture has negative impact in rural communities on water conservation, water supply and water storage. Water scarcity and food security in rural communities are jeopardized by lack of water for irrigation, insufficient food production to meet the needs of the communities. But there are many opportunities and chances that if proper procedures and measures are put in place, water scarcity can be dealt with once and for all. In order to improve the standard of living of the African people, there must be improvements on the reduction of high birth rate to a maximum of three per household, this would help to preserve, conserve and use water for a long period of time. People should avoid unnecessary damage to environment i.e. cutting of trees, dumping dangerous chemicals in rivers, dams and avoiding water pollution, then the threat to water availability can be reduced.

\section{Recommendation}

It is crucial for water to be conserved in order to use it economically as this will address lack of food and unemployment to communities. If small irrigations schemes (SIS) are transformed, they will be able to secure water rights and chance of their growth will be maximised.

To farmers

Famers should utilize water resources and strive to improve food production in order to be productive and maintain food Security status positive. Food production is on demand from the food supply chain and production markets, and these and other stakeholders must be involved when addressing food security issues from the grass root level. Awareness and training must be encouraged between smallholders' farmers, department of agricultural and the communities to achieve maximum cooperation on production and sustainability. 
For policy

The government should encourage all sectors that are dealing with water to discuss water challenges so that they do policy formation and policy reviews periodically, in order to guide and guard the implementation of water usage. This should involve state departments, local Municipalities and famers association and other stakeholders who are affiliated to the agricultural sector. Water Scarcity can be resolved by involving different stakeholders and different state bodies globally. The use of water must be debated, demonstrated and be taught to all water users to avoid unnecessary water losses. Water supply and water conservation must be funded so that there can be bulk water stored for future use. It is in this note that we can have guarantee on food security if water is properly conserved.

For Research

Information should be made available to all sectors and people to provide clear direction on how to conserve and use water. Furthermore, there should be researches that will be carried out on water scarcity that will inform researchers, the government as well as private sector about the findings, in order for them to scrutinize issues surrounding the intended research.

The transmission of white pepper prices from the producer market to the exporter market, from the producer market to the world market, and from the exporter market to the world market shows that in the short period it runs asymmetrically, whereas in the long period it runs symmetry. On the other hand, the transmission of white pepper prices from the world market to the exporter market runs symmetrically in the short period but in the long period it runs asymmetrically. The pepper association in the Bangka Belitung Islands Province provides information on the price of white pepper that is easily accessed by farmers. In addition, farmers still have a weak bargaining position in the decision to determine the selling price of white pepper so farmers should sell collectively, for example by forming groups in marketing white pepper to improve their bargaining position.

\section{ACKNOWLEDGEMENTS}

I would like to express my sincere appreciation to the Institute for Rural Development (IRD) under the leadership of Prof J. Francis for the support I received, that enabled me to successfully complete my research paper. I deeply acknowledge the guidance, moral support, advice, supervision, assistance and encouragement in my work from my supervisor Dr. M Manjoro, co- supervisor Dr. J. Zuwarimwe and co-supervisor Dr. M Tjale. My sincere gratitude to the University of Venda for affording me the opportunity to study this honours degree. The authors are grateful for the partnership they have with USAID who financially assisted in publication of this journal (subawardee number 20000092). 


\section{REFERENCES}

Averbeke, W. van, Denison, J., \& Mnkeni, P. (2011). Smallholder Irrigation Schemes in South Africa: A Review of Knowledge Generated by the Water Research Commission. Water SA, 37(5). https://doi.org/10.4314/wsa.v37i5.17

Azene, Y. B., Zeleke, M. T., \& Chekole, A. B. (2018). Vulnerability of Mountain Communities to Climate Change and Natural Resources Scarcity in Northwest Ethiopia:The Case of Debark Woreda. Journal of Degraded and Mining Lands Management, 6(1), 1467-1482. https://doi.org/10.15243/jdmlm.2018.061.1467

Crookes, C., Hedden, S., \& Donnenfeld, Z. (2018). A Delicate Balance : Water Scarcity in South Africa. ISS Southern Africa Report, 2018(13), 1-24. https://doi.org/10.10520/EJC-1486c3180a

Darko, R. O., Yuan, S., Hong, L., Liu, J., \& Yan, H. (2016). Irrigation, A Productive Tool for Food Security - A Review. Acta Agriculturae Scandinavica, Section B - Soil E Plant Science, 66(3), 191-206. https://doi.org/10.1080/09064710.2015.1093654

Daus, M., Koberger, K., Gnutzmann, N., Hertrich, T., \& Glaser, R. (2019). Transferring Water While Transforming Landscape: New Societal Implications, Perceptions and Challenges of Management in the Reservoir System Franconian Lake District. Water, 11(12), 2469. https://doi.org/10.3390/w11122469

Department of Agriculture, Forestry \& Fisheries. (2015). Irrigation strategy for South Africa. Government publishers: Pretoria.

Dotse, L. N. . (2016). Exploring the Relationship Between Water Scarcity on Food and Nutritional Security in Rural Households in the Nqgeleni Location, Eastern Cape. University of The Witwatersrand.

Esmaeili, A., \& Vazirzadeh, S. (2009). Water Pricing for Agricultural Production in the South of Iran. Water Resources Management, 23, 957-964. https://doi.org/10.1007/s11269-008-9308-y

Fanadzo, M., Chiduza, C., \& Mnkeni, P. N. S. (2010). Overview of smallholder irrigation schemes in South Africa: Relationship between farmer crop management practices and performance. African Journal of Agricultural Research, 5(25), 3514-3523. https://doi.org/https://doi.org/10.5897/AJAR10.001

Fanadzo, M., \& Ncube, B. (2018). Challenges and Opportunities for Revitalising Smallholder Irrigation Schemes in South Africa. Water SA, 44(3), 436-447. https://doi.org/10.4314/wsa.v44i3.11

Food and Agriculture Organization. (2000). Socio-Economic Impact of Smallholder Irrigation Development in Zimbabwe: Case Studies of Ten Irrigation Scheme.

Food and Agriculture Organization. (2011). The State of the World's Land and Water Resources for Food and Agriculture: Managing Systems at Risk. Earthscan. 
Gashu, D., Demment, M. W., \& Stoecker, B. J. (2019). Challenges and Opportunities to The African Agriculture and Food System. African Journal of Food, Agriculture, Nutrition and Development, 19(1), 14190-14217. https://doi.org/10.18697/ajfand.84.BLFB2000

Haacker, E. M. K., Sharda, V., Cano, A. M., Hrozencik, R. A., Núñez, A., Zambreski, Z., Nozari, S., Smith, G. E. B., Moore, L., Sharma, S., Gowda, P., Ray, C., Schipanski, M., \& Waskom, R. (2019). Transition Pathways to Sustainable Agricultural Water Management: A Review of Integrated Modeling Approaches. JAWRA Journal of the American Water Resources Association, 55(1), 6-23. https://doi.org/10.1111/17521688.12722

Hadebe, S. T., Modi, A. T., \& Mabhaudhi, T. (2016). Drought Tolerance and Water Use of Cereal Crops: A Focus on Sorghum as a Food Security Crop in Sub-Saharan Africa. Journal of Agronomy and Crop Science, 203(3), 177-191. https://doi.org/10.1111/jac.12191

Hamilton, R. (2019). From Water Management to Water Stewardship-A Policy Maker's Opinion on the Progress of the Mining Sector. Water, 11(3), 438. https://doi.org/10.3390/w11030438

Hunink, J., Simons, G., Suárez-Almiñana, S., Solera, A., Andreu, J., Giuliani, M., Zamberletti, P., Grillakis, M., Koutroulis, A., Tsanis, I., Schasfoort, F., Contreras, S., Ercin, E., \& Bastiaanssen, W. (2019). A Simplified Water Accounting Procedure to Assess Climate Change Impact on Water Resources for Agriculture Across Different European River Basins. Water, 11. https://doi.org/10.3390/w11101976

Koda, K., Girmay, G., Berihu, T., \& Nagumo, F. (2019). Reservoir Conservation in a MicroWatershed in Tigray, Ethiopian Highlands. Sustainability, 11(7), 2038. https://doi.org/10.3390/su11072038

Koppen, B. van, Nhamo, L., Cai, X., Gabriel, M. J., Sekgala, M., Shikwambana, S., Tshikolomo, K., Nevhutanda, S., Matlala, B., \& Manyama, D. (2017). Smallholder Irrigation schemes in the Limpopo Province, South Africa. In IWMI Working Papers (Vol. 174). https://doi.org/10.5337/2017.206

Machethe, C., Mollel, N., K Ayisi, M. M., Anim, F., \& Vanasche, F. (2004). Smallholder Irrigation and Agricultural Development in the Olifants River Basin of Limpopo Province: Management Transfer, Productivity, Profitability and Food Security Issues. http://citeseerx.ist.psu.edu/viewdoc/download?doi=10.1.1.458.9268\& rep=rep1\&typ $\mathrm{e}=\mathrm{pdf}$

Mancosu, N., Snyder, R. L., Kyriakakis, G., \& Spano, D. (2015). Water Ccarcity and Future Challenges for Food Production. Water, 7, 975-992.

Maponya, P., \& Mpandeli, S. (2016). Drought and Food Security in Limpopo Province, South Africa. In 2nd World Irrigation Forum (Issue November, pp. 1-8). 
Maponya, P., \& Mpandeli, S. (2012). Impact of drought on food scarcity in Limpopo province, South Africa. African Journal of Agricultural Research, 7(37), 5270-5277. https://doi.org/10.5897/AJAR12.1453

Maponya, P., Mpandeli, S., \& Oduniyi, S. (2013). Climate Change Awareness in Mpumalanga Province, South Africa. Journal of Agricultural Science, 5(10), 273-282.

McDaniel, R. L., Munster, C., \& Nielsen-Gammon, J. (2017). Crop and Location Specific Agricultural Drought Quantification: Part III. Forecasting Water Stress and Yield Trends. Transactions of the ASABE, 60(3), 741-752. https://doi.org/10.13031/trans. 11651

Meng, Q., Chen, X., Lobell, D. B., Cui, Z., Zhang, Y., Yang, H., \& Zhang, F. (2016). Growing Sensitivity of Maize to Water Scarcity Under Climate Change. Scientific Reports, 6. https://doi.org/10.1038/srep19605

Mengistie, D., \& Kidane, D. (2016). Assessment of The Impact of Small-Scale Irrigation on Household Livelihood Improvement at Gubalafto District, North Wollo, Ethiopia. Agriculture, 6. https://doi.org/10.3390/agriculture6030027

Njoko, S. L. (2014). Smallholder Farmers' Willingness and Ability to Pay for Improved Irrigation: A Case of Msinga Local Municipality, KwaZulu-Natal Province. University of KwaZulu-Natal Pietermaritzburg.

Perret, S. (2002). Water policies and smallholding irrigation schemes in South Africa: a history and new institutional challenges. Water Policy, 4(3), 283-300. https://doi.org/10.1016/S1366-7017(02)00031-4

Schreiner, B., Tapela, B., \& Koppen, B. van. (2010). Water for Agrarian Reform and Rural Proverty Eradication: Where is The Leak? Overcoming Inequality and Structural Poverty in South Africa: Towards Inclusive Growth and Development.

Simonovic, S. P., \& Arunkumar, R. (2016). Quantification of resilience to water scarcity, a dynamic measure in time and space. Proceedings of the International Association of Hydrological Sciences, 373, 13-17. https://doi.org/10.5194/piahs-373-13-2016

Taye, M. T., Dyer, E., Hirpa, F. A., \& Charles, K. (2018). Climate Change Impact on Water Resources in The Awash Basin, Ethiopia. Water, 10, 1-16. https://doi.org/10.3390/w10111560

Thomas, A. B. (2004). Research Skills for Management Studies. Routledge. https://doi.org/10.4324/9780203006146

Tlou, T., Mosaka, D., Perret, S., Mullins, D., \& Williams, C. J. (2006). Investigation of different farm Tenure Systems and support Structure for establishing Small-Scale Irrigation in long Term Viable conditions. 
World Health Organization. (2009). Summary and Policy Implication Vision 2030: The Resilience of Water Supply and Sanitation in the Face of Climate Change.

Yokwe, S. C. B. (2005). Investigation of the economics of water as used by smallholder irrigation farmers in South Africa [University of Pretoria]. https://repository.up.ac.za/bitstream/handle/2263/26912/00dissertation.pdf?seque nce $=1$ 